MAKÜ FEBED

ISSN Online: 1309-2243

http://dergipark.ulakbim.gov.tr/makufebed

Mehmet Akif Ersoy Üniversitesi Fen Bilimleri Enstitüsü Dergisi 8(1): 22-33 (2017)

The Journal of Graduate School of Natural and Applied Sciences of Mehmet Akif Ersoy University 8(1): 22-33 (2017)

Derleme Makale / Review Paper

\title{
İlkokul Binalarının Ekolojik Açıdan İyileştirilmesi: İstanbul Tuzla Tapduk Emre İlkokulu Örneği
}

\author{
Tülay T. KARADAYI ${ }^{1}$, İzzet YÜKSEK²*, İrem TUNÇBiZ ${ }^{3}$ \\ ${ }^{1}$ Gebze Teknik Üniversitesi, Mimarlık Fakültesi, Çayırova, Gebze, Kocaeli \\ ${ }^{2}$ Celal Bayar Üniversitesi, Güzel Sanatlar Tasarım ve Mimarlık Fakültesi, Şehzadeler, Manisa \\ ${ }^{3}$ Serbest Mimar \\ Geliş Tarihi (Received): 01.12.2016, Kabul Tarihi (Accepted): 20.02.2017 \\ $\square$ Sorumlu Yazar (Corresponding author): izzet.yuksek@cbu.edu.tr \\ (C) +902362348280 且 +902362371675
}

ÖZ

Günümüz çağdaş yaşamı teknolojiye ve endüstriye dayalı olarak gelişmekte ve sürdürülebilirlikten uzaklaşmaktadır. Kentli nüfus oranı artmakta ve bu artışa bağlı olarak kent sınırları genişlemektedir. Büyüyen kentler yapılaşmayı arttırmaktadır. Hızlı sanayileşme ve kentleşme sonucu doğal kaynaklar hızla tükenmekte, çevre kirliliği ve küresel ısınma insan yaşamını tehdit edici seviyeye ulaşmaktadır. Başta enerji olmak üzere hammadde kaynaklarının önemli bir kısmı yapıların üretim ve kullanım sürecinde gerçekleşmektedir. Mevcut yapıların önemli bir kısmı ekolojik kaygılar olmaksızın inşa edildiklerinden özellikle doğal kaynaklardan elde edilen enerjinin yoğun olarak tüketilmesine neden olmaktadır. Yaşanılan süreçte yeni yapıların ekolojik özelliklere sahip olarak inşa edilmesi kadar, mevcut yapıların da ekolojik özelliklere sahip olacak şekilde yenilenmesi gerekmektedir. Bu kapsamda özellikle eğitim çağındaki çocukların sürdürülebilirlik ve çevre bilincini yaşayarak öğrenmesini sağlayacak ortamların okullarında oluşturulması önemlidir. Ekolojik okul yapıları sürdürülebilirlik kavramını hem yapısal hem de eğitim aracı olarak içinde eğitim gören öğrencilere katkıda bulunacaktır. . Bu amaçla İstanbul ili içerisinde tipik bir okul yapısı seçilmiş, analiz edilerek bu yapıya ekolojik iyileştirme amaçlı önerilerde bulunulmuştur.

Anahtar Kelimeler: Ekolojik mimari, ekolojik okul, sürdürülebilirlik eğitimi, doğal kaynak tüketimi

\section{Ecological Improvement of Primary School Buildings: The Sample of Tuzla Tapduk Emre Primary School, İstanbul, Turkey}

\begin{abstract}
Today's contemporary life is developing on the basis of technology and industry and is moving away from sustainability. Urban population ratio is increasing and city boundaries are expanding due to this increase. Growing cities are increasing the number of buildings. natural resources are quickly depleting, environmental pollution and global warming are threatening levels of human life due to the urbanization and rapid industrialization. An important part of the raw material resources, especially energy, is realized during the production and usage of the buildings. Since a significant part of the existing buildings are produced without ecological concerns, they cause intensive use of natural resources, especially energy. Existing buildings must be renovated to have ecological characteristics and construction of new buildings with ecological characteristics in this process. In this context, it is important to create environments that will enable children in education age to achieve sustainability and environmental awareness. School structures in this way will be able to use the concept of sustainability as both a structural and an educational tool. For this
\end{abstract}


purpose, a sample school building was selected and analyzed within the province of Istanbul and were made suggestions for ecological improvement.

Keywords: Ecological architecture, ecological school building, sustainability education, natural resource consumption

\section{GíRiş}

Özellikle kendisi de bir eğitim aracı olan temel eğitim binalarının ekolojik kriterlere uygun olarak tasarlanması ekolojik sürdürülebilirliğin devamı açısından çok önemlidir. Çünkü eğitim yapıların fiziksel koşulları eğitim şartlarını, öğrenmeyi ve kullanıcıların sağlığını etkilemektedir. Daha temiz bir iç hava kalitesi, doğal aydınlatma vb. gibi ekolojik yapı kavramının gerektirdiği koşulların sağlanması daha iyi öğrenme koşulları sağlamakta ve öğrenci başarısını artırmaktadır.

Eğitim binalarının sürdürülebilir tasarımıyla elde edilecek çevresel amaçlı getirilerin yanı sıra, kullanıcıların (öğrencilerin) konfor koşullarının ve performanslarının da maksimum düzeye çıkartılabileceği çeşitli çalışmalarca vurgulanmaktadır. Maiden'e göre eğitim binasının koşulları, öğrencilerin davranış ve başarılarını büyük ölçüde etkilemektedir (Maiden ve Foreman, 1998). Meek (1995)'e göre; öğrencilerin öğrenme potansiyelini arttıracak birer araç olarak mimari elemanların kullanımı, güncel bir eğitim reformu düşüncesidir. Eğer eğitim-öğretim ve uygulama süreçlerinin yeniden yapılandırılması hedefleniyorsa, bu faaliyetlerin gerçekleşeceği fiziksel bağlamın da düşünülmesi kaçınılmazdır (Meek, 1995). Ülkemizdeki temel eğitim okullarının sürdürülebilirlik kriterleri doğrultusunda tasarlanması ve/veya iyileştirilmesi kapsamında sadece günlük yaşam süreci içinde nüfusun yaklaşık \%15'ine sürdürülebilirlik bilincinin öğretilmesi çok büyük bir gelişme olacaktır. Genç bir nüfusa sahip olan ülkemiz için konunun önemi büyüktür. Ülkemizde temel eğitim kademesinde, resmi okullarda eğitim gören 11 milyon 79 bin 517 öğrenci özel okullarda ise 701 bin 798 öğrenci eğitim görmektedir (MEB, 2016). Temel eğitim okullarında yapılacak bu tür yeni bir yapılanma ile sadece eğitim ve öğretimin gerçekleştiği binaların içinde yaşayanlar değil, toplumun diğer fertleri de (öğrencilerin aileleri, çevre halkı) sürdürülebilirlik konularında dolaylı da olsa bilgilenecektir.

Bu çalışmanın amacı mevcut ilkokul yapılarının daha ekolojik hale getirilip çevresel zararlarının azaltmanın mümkün olabileceğini göstermektedir. Bunun için, İstanbul ili içerisinde örnek bir okul yapısı seçilip analiz edilerek ekolojik iyileştirme amaçlı önerilerde bulunulmuştur. Çalışma sonucunda elde edilecek bilgiler başka okulların iyileştirilmesi için örnek olabilir. Bu önerilerin az bir maliyetle uygulanabileceği düşünülmektedir. Bu tür uygulamaların artmasıyla mevcut yapı stoku en az mü- dahaleyle çevreye duyarlı hale getirilecektir. Bu okullarda eğitimlerinin ilk aşamasını alan öğrenciler ise; bu bilinç ile gelecek nesillerin şekillenmesini sağlayacaktır.

\section{İlkokullarda Sürdürülebilir Tasarım Anlayışı}

Eğitim; kişilerin ve toplumları şekillenmesini sağlayan en önemli olgudur. Eğitim verilen yapılar ise bu açıdan önemlidirler. Özellikle 7-10 yaş arası, çocuk gelişiminin ve kişilik oluşumunun büyük ölçüde sağlandığı ilkokul yapıları ayrı bir öneme sahiptir.

İlkokul çağları; çocuk gelişiminin, davranış ve alışkanlıkların oluştuğu yaşlardır. Bu dönemde kazanılan alışkanlıklar, insan ömrü boyunca olumlu ya da olumsuz etkilere sahiptir. Bu yüzden ilkokul eğitiminin verildiği yapılar özellikli olmalıdır. Bu yapılar çocukların ufkunu açacak yenilikçi, çok yönlü ve farklı imkânlara sahip olmalıdır. Bu açıdan ilkokul yapılarının sürdürülebilir özellik taşıması ayrı bir önem kazanmaktadır.

Okulların, topluluklar üzerinde, sınıfların içerisinde gerçekleşen eğitimin ötesine geçen bir etkisi vardır. Sürdürülebilir bir okul araç kullanmayı azaltmak, yeme alışkanlıklarını değiştirmek ve enerji tasarrufu davranışlarını göstermek gibi bir misyona sahiptir. Bu etkiler, çok güçlü olabilmektedirler. Sürdürülebilir okullar ise öğrencilerin her yaptıkları eylemin dünya üzerindeki etkilerinin farkında olmaları için ve beklentilerini yeniden düzenleme ve bir sonraki jenerasyonun temel beklentilerini yenilemede büyük rol oynamaktadırlar (Tonguç, 2012).

Çocukların kimlik ve ilk becerilerini kazandıkları ilkokul yapılarının sürdürülebilir açıdan tasarlanmaları, sadece çocukların değil o toplumun da şekillenmesini, olumlu yönde gelişmesini sağlayacaktır. Bu amaçla tasarlanacak yapıların belirli kriterler çevresinde şekillenmesi ve kendini geliştirmesi gerekmektedir.

Okul binasının tasarım özellikleri ve yapı bileşenleri öğrenci öğrenmesini etkilemektedir. Yapıdaki ısısal çevre ve gürültü seviyesi öğrenci üzerinde olumlu veya olumsuz etki yapabilir (Earthman, 2002). Taylor (2009)'a göre, "Öğrenme ortamlarının yaşanabilirliği birincil meseledir, çünkü çocukların bedenleri gelişme sürecindedir ve dış ajanlar bu büyüme ve gelişmeyi bozabilir, sağlık ve performansı risk altına alabilir. Çocuklar zayıf hava kalitesi, doğal ışık eksikliği veya gürültü gibi çevresel tehlikelere karşı özellikle savunmasızdır (Taylor, 2009). 
Yeşil okul tasarımı, binaları günışığına açmayı ve HVAC (Isıtma, Havalandırma, İklimlendirme) sistemleri için enerji yüklerini azaltma ve enerji maliyetlerini düşürme genel amacı ile öğrenme ortamlarının yaşanabilirliğine yönelik tüm bu tehditlere karşı görüş ve tepki vermeyi amaçlıyor. Bu nedenle, yeşil okul tasarımı, diğer bir deyişle sürdürülebilir okul tasarımı, sağlıkı ve etkili öğrenme ortamları için vazgeçilmez bir unsurdur.

Dudek (2000), okul tasarımının gereklerini aşağıdaki şekilde belirlemiştir:

- Mekânsal konfigürasyonlar

- Akustik tasarım

- Sürdürülebilirlik

- Açık alanlar.

Dolayısıyla, bu gereksinim listesine göre sürdürülebilirliğin bir okulun genel tasarımında kilit faktör olduğu görülebilir.

Sürdürülebilir okulların faydaları (Gelfand, 2010);

- Daha yüksek öğrenci puanları (sosyal sürdürülebilirlik),

- Daha düşük işletme maliyetleri (ekonomik sürdürülebilirlik),

- Artan öğrenci dikkatini (sosyal sürdürülebilirlik),

- Gelişmiş öğretmen performansı ve memnuniyeti (sosyal sürdürülebilirlik),

- Artan bina ömrü (ekonomik sürdürülebilirlik),

- Daha düşük çevresel etki ve değişen tutumlar (ekolojik sürdürülebilirlik)

Poudre Bölgelerinin Sürdürülebilir Okul Tasarım Kuralları'nda, sürdürülebilir okullar aracılığıyla elde edilebilecek hedefler şu şekilde düzenlenmiştir (Dorsey ve L'Esperance, 2000):

- Öğrenci performansını ve devamını arttırmak,

- Sürdürülebilir tasarım ilkelerini öğretmek,

- Doğal manzara ile uyum sağlamak,

- Yüksek kaliteli aydınlatma,

- Daha az enerji tüketmek,

- Malzemeleri ve doğal kaynakları korumak,

- Kapalı ortamın kalitesini artırmak,

- Suları korumak

Ford (2007)'a göre, çevre dostu okullar, mimari karakterden zengindir ve yüksek performanslı tasarım ilkelerini bünyesinde barındırır. Bu yüksek performanslı tasarım ilkelerine göre kullanılan araçlar şunlardır (Ford, 2007):

- Su: Yağmur suyu toplama, atık su arıtımı, yağmur suyu yönetimi, susuz peyzaj, yüksek verimli sulama sistemleri, biyolojik filtrasyon, su tasarrufu sağlayan sıhhi tesisat armatürleri,

- Enerji: fotovoltaik kullanımı, pasif güneş stratejileri, harici güneş gölgelemeleri, rüzgâr türbinleri, yüksek performanslı bina kabuğu, ısı pompaları ile birlikte toprak kaynağı jeotermal, termal kütle, web tabanlı veya bilgisayar kontrollü yüksek verimli mekanik sistemler, yeşil çatılar, "Serin" çatılar,

- İç hava kalitesi: doğal havalandırma, güneş bacaları, değişken havalandırma, rüzgâr duvarları, düşük VOC içeren malzeme kullanımı,

- Geri dönüştürülmüş ve yeşil malzemeler: şantiyede geri dönüşüm, yapı malzemeleri içinde geri dönüştürülmüş içerik, sertifikalı yeşil yapı malzemeleri,

- Ulaştırma ve çok amaçlı, alternatif ulaşım sistemleri, değişen eğitim stratejileri ile uyarlanabilir okul bitkileri ve mesai sonrası topluluk merkezleri olarak hizmet veren okullar olarak ele alınmaktadır.

Gelfand (2010), sürdürülebilir okullarda dikkate alınması gereken ana tasarım stratejilerinin temel unsurlarını aşağıdaki şekilde belirlemiştir:

- Gün ışığı,

- Yapı strüktürü ve kabuğu,

- Isıtma, havalandırma, soğutma ve sıhhi tesisat,

- Peyzaj ve yerleşim alanı tasarımı.

Taylor (2009)'a göre, okulları sürdürülebilir yaşam ortamları olarak tasarlarken; yerleşim yeri seçimi ve tasarımı, maksimum enerji yararına okulun güneş yönelimi, rüzgâr enerjisi vb. incelenebilir. Okullarda sürdürülebilirlik sağlamak için tasarım potansiyelleri aşağıdaki gibi belirlenmiştir (Taylor, 2009):

- Su toplama ve geri dönüşüm sistemlerinin sağlanması,

- Öğrenme için geçiş hacimleri tasarlama, sınıf alanlarına uzantılar veya dışa (sundurma, avlu, gölgeli alanlar, kış bahçesi, sulu veya kuru havuzlar vb) bağlantılar.

- Tarım ve buna bağlı yaşam becerileri için tasarım,

- Öğrencilerin gözlemlemeleri veya bakım yapmaları için yaşama ortamı oluşturmak veya var olan yaşam alanlarını korumak.

- Öğrenci bakımı ve sorumluluk için tasarlanmak, sadece kapıcı istihdam değil,

- Yerel malzeme, vernaküler mimari ve peyzaj tekniklerini kullanmak.

Her tür okula uygulanabilecek temel ve uygun maliyetli sürdürülebilir planlama ve tasarım stratejileri, aşağıdaki gibidir (LPA, 2009):

- Peyzaj Mimarlığı,

- Su korunumu ve yağmursuyu yönetimi,

- Malzemeler ve kaynaklar,

- İç hava kalitesi,

- Planlama ve tasarım,

- Dış tasarım,

- Cephe tasarımı,

- Termal gecikme ve günlük sıcaklık değişimi, 
- Çatı.

Yukarıda verilen kaynaklar ışığında sürdürülebilir okul tasarım prensipleri şu şekilde sınıflandırılabilir;

Enerji korunumu: yüksek performanslı yapı kabuğu tasarımı, yüksek performanslı HVAC sistemlerinin kullanımı, pasif ısıtma ve pasif soğutma sistemlerinin kullanımı, gün ışığından yararlanma, $P V$ panel ve rüzgâr türbini kullanımı, yeşil çatı, termal kütle kullanımı, enerji etkin elektrikli aletlerin kullanımı.

Su korunumu: yağmur suyu toplama, yağmur suyu yönetimi, atık suyun arıtımı, su etkin peyzaj kullanımı, verimli sulama sistemlerinin kullanımı, su etkin armatürlerin kullanımı.

Malzeme korunumu: şantiyede geri dönüşüm, geri dönüşüm içerikli yapı malzemesi kullanımı, yöresel malzeme ve yapım tekniklerinin kullanımı.

İç hava kalitesi: Doğal ve değişken havalandırma, düşük VOC içerikli yapı malzemesi kullanımı, güneş bacaları ve rüzgâr duvarları kullanımı.

Okulun yerleşim yeri tasarımı: doğal çevrenin ve doğal konturların korunması, olabildiğince fazla açık alan tasa-

ISTANBUL, TUZLA, TAPDUK EMRE İLKOKULU ÖRNEĞINDE İLKOKUL YAPISININ EKOLOJIKK IYYILEŞTIRME OLANAKLARININ ARAŞTIRILMASI

\section{Mimari ve Çevresel Özellikleri}

2007-2008 eğitim öğretim yılında eğitime başlayan Tapduk Emre İlkokulunda, anaokulu ve ilkokul eğitimi veren 20 ilköğretim dersliği, 4 ana sınıf dersliği bulunmaktadır. Ancak $4+4+4$ sistemi ile okulda yapılan düzenlemeler rımı, yöresel iklime uygun peyzaj, açık alanların bitkilendirilmesi, okul bahçesinin değişik etkinliklere uyumlu planlanması, okul ve bahçesinin farklı amaçlarla halkla bütünleşik kullanıma uygun tasarlanması. Okulun konumunun farklı ulaşım şekillerine uygun seçilmesi, bahçede daha az geçirimsiz yüzey kaplaması yapılması, ISı absorbe etmeyen kaplama malzemelerinin kullanımı.

Bu çalışmada da İstanbul' da, tasarımında çevresel kaygılar düşünülmeden inşa edilmiş bir ilkokul yapısı seçilerek ekolojik açıdan iyileştirme olanakları araştırılmıştır. Ülkemizde sürdürülebilirlik kavramı son yıllarda gündeme geldiği için mevcut yapı stokunun büyük bir bölümü bu tür özelliklerden uzaktır. Bunun için baştan doğru kararlar almak gerekmektedir. Ancak bu yapıları sonradan bazı düzenlemeler yaparak ekolojik açıdan iyileştirmek mümkün olabilir. Bu şekilde tamamen olmasa bile yapının çevreye verdiği zararları azaltmaya katkıda bulunabilir.

Aşağıdaki bölümde bu amaçla Tuzla İstanbul'da seçilen İstanbul, Tuzla, Tapduk Emre ilkokul yapısının ekolojik açıdan araştırılan iyileştirme olanaklarını sunulmaktadır. Bunun için öncelikle yapının çevresel açıdan mevcut durumu tespit edilerek olumsuzluklar ortaya konmuş, daha sonrada bunları iyileştirecek önerilerde bulunulmuştur.

sonucu ilkokul derslikleri sayısı 25'e çıkarılmıştır. Okul ikili öğretim sistemini uygulamaktadır. Devam eden 2014-2015 eğitim öğretim yılında 90 öğretmen ve 2480 öğrenci ile eğitime devam edilmektedir. 4 katlı olan okul yapısı; doğu-batı aksında yerleştirilmiştir. Koridor bu aks boyunca devam ederken sınıflar ve diğer mekânlar bu koridorun sağında ve solunda yani kuzey ve güney cephede yer almaktadır (Şekil 1, 2, 3). 

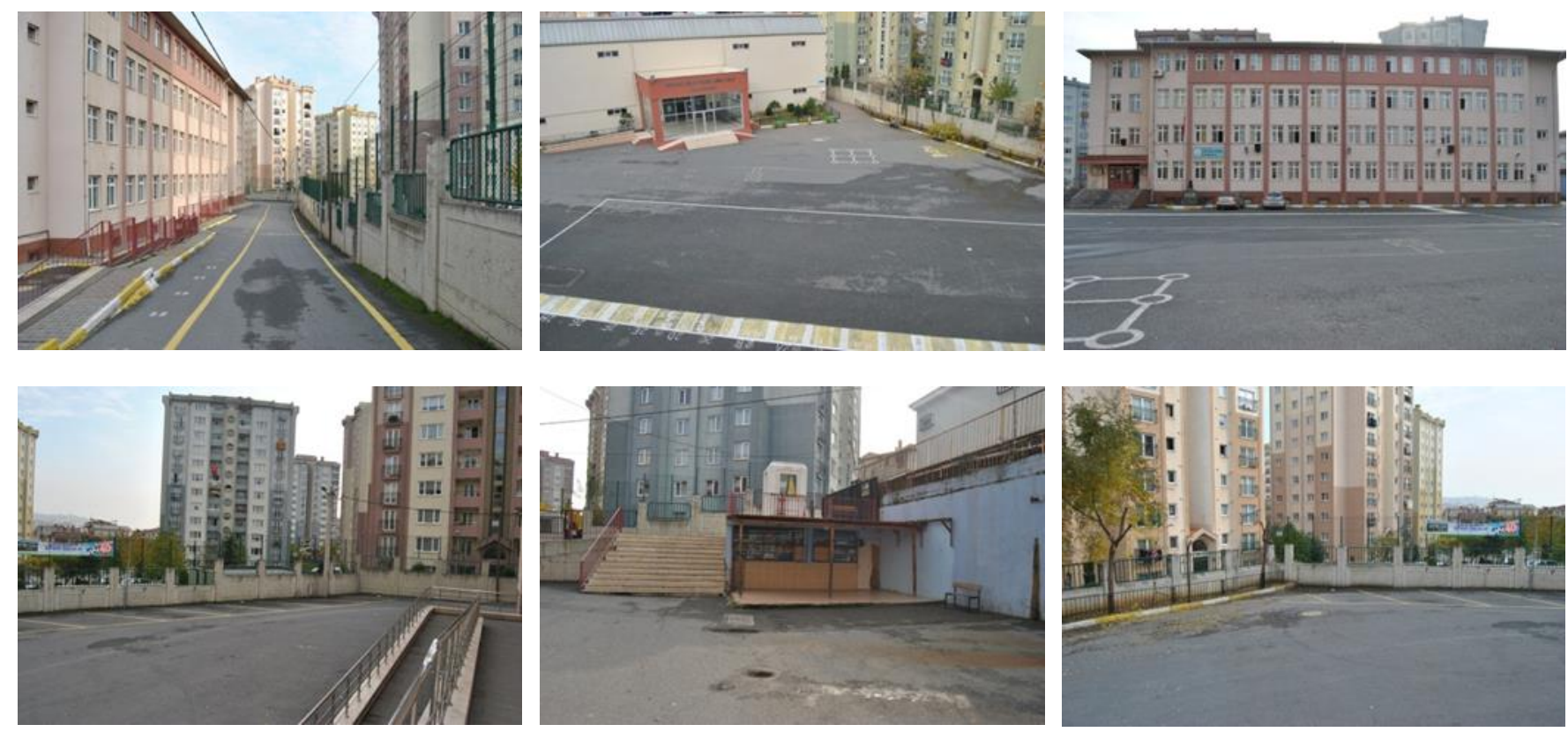

Şekil 1. Tapduk Emre İlkokulu dış mekândan görünüşler
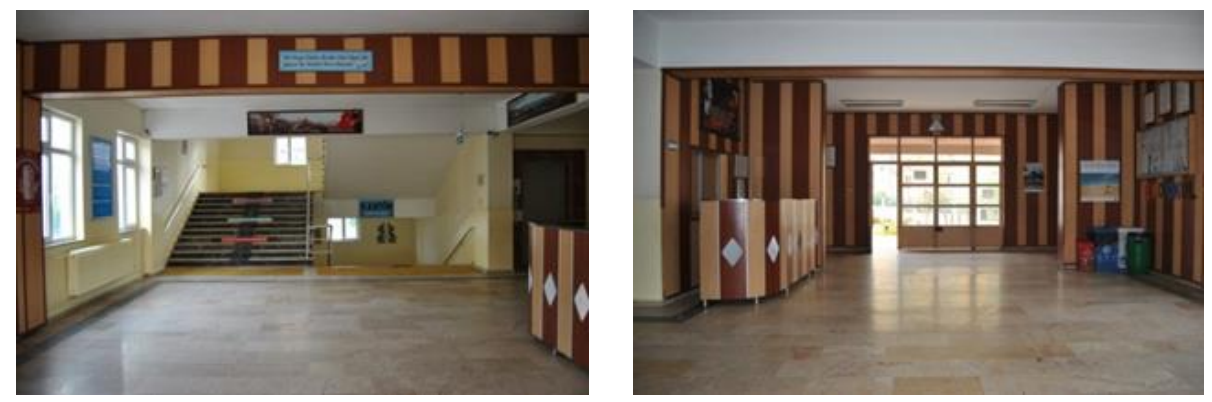

Şekil 2. Okul ana giriş kapısı
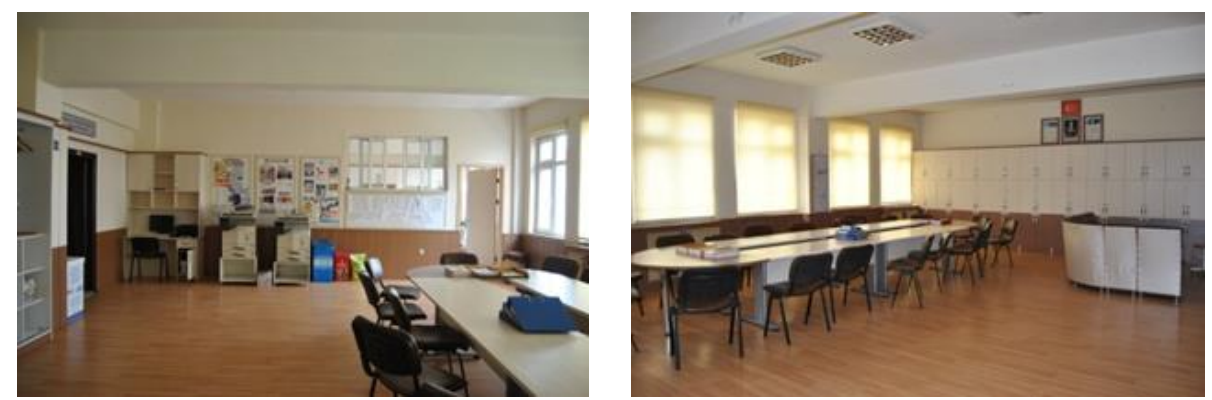

Şekil 3. Öğretmenler odası 

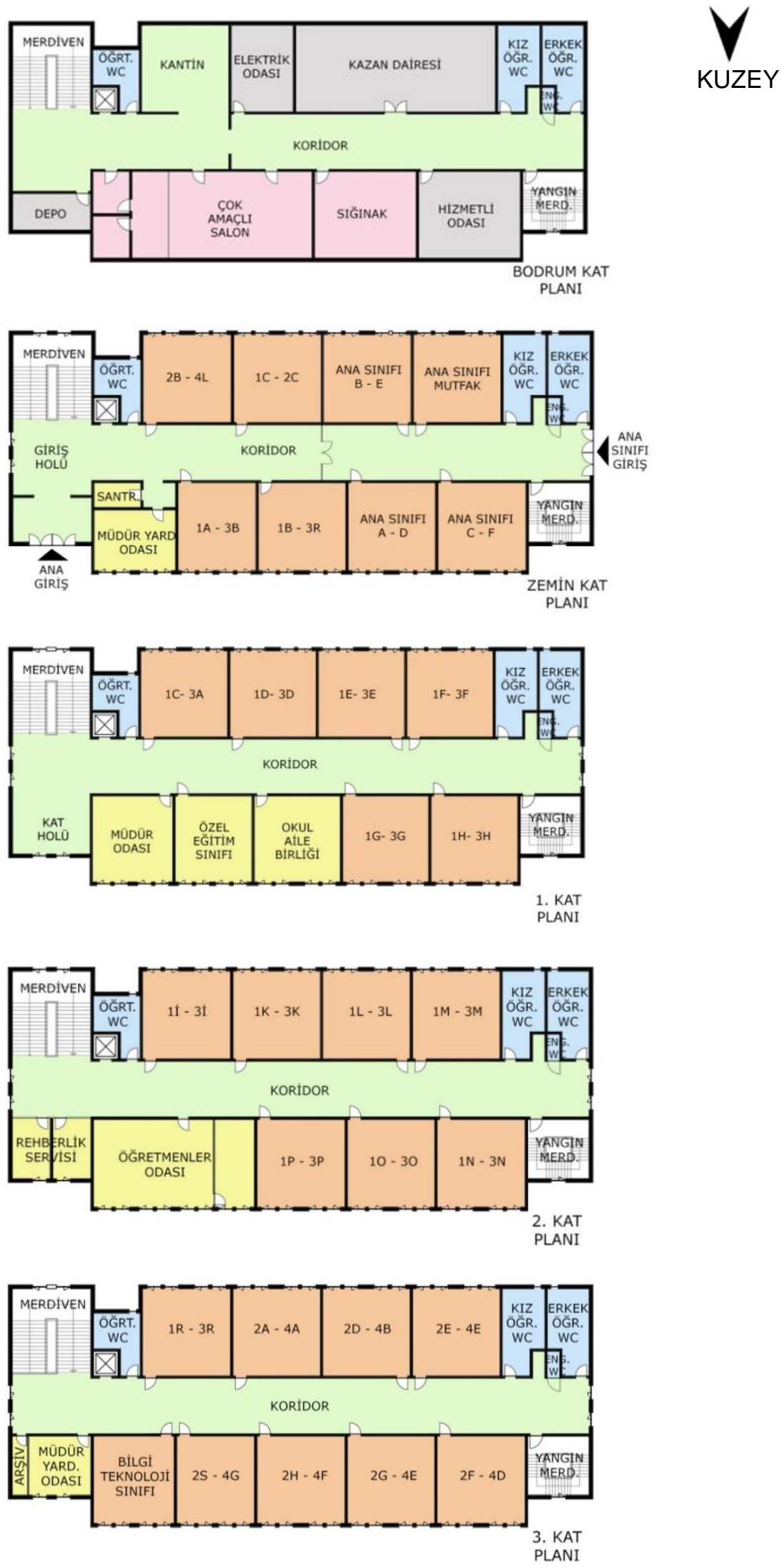

Şekil 4. Tapduk Emre İlkokulu kat planları 

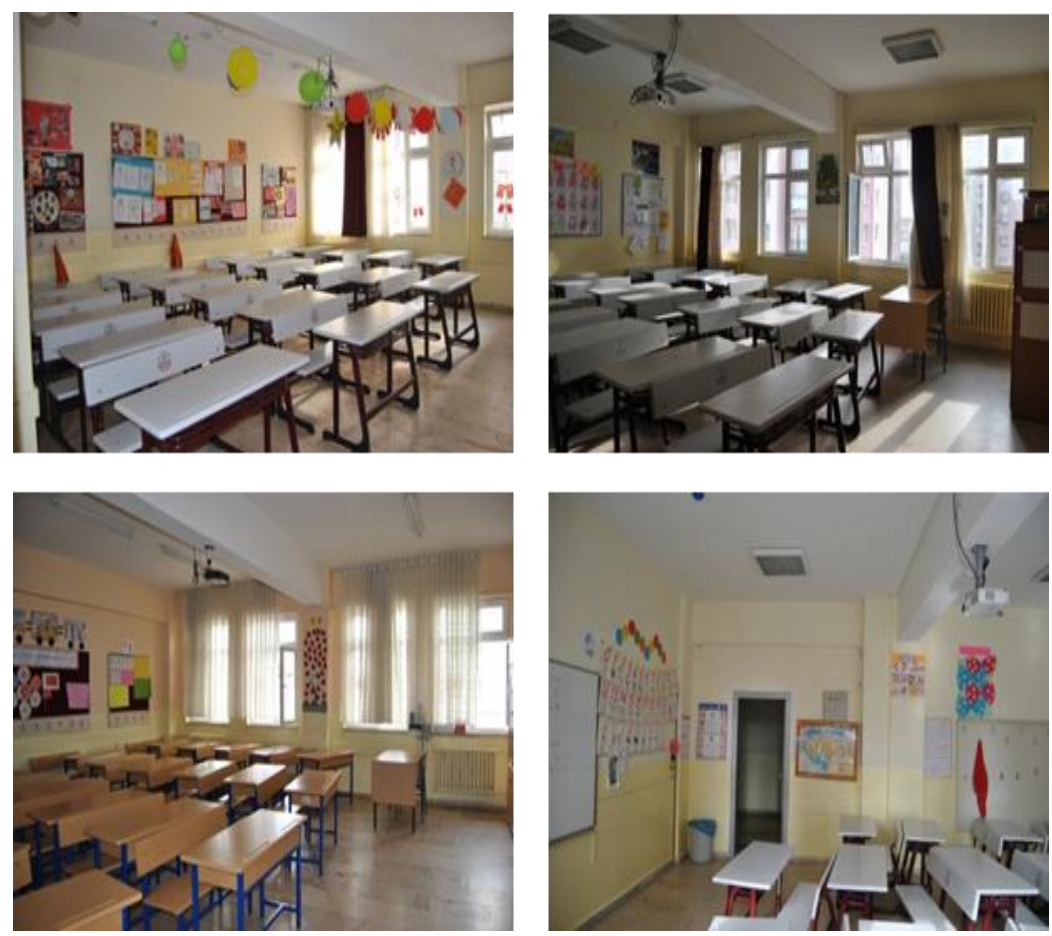

Şekil 5. Standart sınıflar

Bodrum katta kantin, çok amaçlı salon, sığınak, kazan dairesi ve teknik odalar, zemin katta; 4 ilkokul sınıfı ve 4 ana sınıfı, müdür yardımcısı odası, birinci katta; 6 sınıf, 1 özel eğitim sınıfı ve müdür odası, ikinci katta; 7 sınıf, öğretmenler odası ve rehberlik servisi, üçüncü katta; 8 sınıf, 1 bilgisayar laboratuvarı ve müdür yardımcısı odası bulunmaktadır. Her katta öğrenci tuvaletleri, öğretmen tuvaletleri ve yangın kaçışları bulunmaktadır. Okulun ısınması doğalgaz ile sağlanmaktadır. Dış cephe yalıtımı bulunmaktadır. Dış mekân zemin kaplaması olarak asfalt kullanıımıştır. Ayrıca ana yapıdan bağımsız; okul bahçesinde spor salonu bulunmaktadır. Toplam okul alanı yaklaşık olarak $3250 \mathrm{~m}^{2}$ dir. Ortalama sınıf ölçüleri ise; $7 \times 7$ m'dir (Şekil 4).

Her sınıfta 4 adet pencere bulunmaktadır. (Pencere ölçüleri; $115 \times 170 \mathrm{~cm}$ ) Sınıf düzenine göre ışık sol taraftan alınmaktadır. Döşeme malzemesi olarak seramik kullanılmıştır. Aydınlatma ise floresan lambalar ile sağlanmaktadır. Oturma düzeni ikili sıralar halindedir. Ancak Milli Eğitim Bakanlığı gereğince 28 öğrenciye göre tip proje olarak geliştirilen sınıf sistemleri sonucu sınıf mevcutlarının artması hareket imkânını kısıtlamakta ve tek tip oturum sistemi kullanılmaktadır. Bu da ders esnasında dikkatin dağıımasını ve öğrenmenin zorlaşmasına neden olmaktadır (Şekil 5).

Koridorlar: Bütün sınıflar tek koridora açılmaktadır. Koridor genişliği $250 \mathrm{~cm}$ 'dir. Doğal ışık alımı koridorun başından ve sonundan sağlanmaktadır. Döşeme malzemesi seramiktir. Aydınlatma yine floresan lambalarla sağlanmaktadır. Ana sirkülasyon merdiveni karşısına gelen kat holleri 4+4+4 sistemi sonrası ihtiyaç gereği kapatılmış ve işlevlendirilmiştir (Rehberlik servisi, veli görüşme alanı, müdür yardımcısı odası...). Bu nedenle koridorlar tam işlevli kullanılamamakta ve aydınlatılamamaktadır. Sınıf ve koridorlarda öğrencilerin el işlerini ve meydana getirdikleri ürünler, çalışmalar sergilenmektedir. Farklı yaş gruplarındaki öğrenciler farklı çalışmaları böylece inceleyebilmektedirler. 4+4+4 sisteminin getirilmesi ve ilkokul yapılarının buna uygun olmaması sonucu; kütüphane, laboratuvar, teknik-kırtasiye alanları sınıfa dönüştürülmüştür. Bunun sonucunda okul sosyal işlevini yitirmiş ve sadece sınıf sisteminin hâkim olduğu tek tip yerlere dönüşmüştür (Şekil 6, 7). 

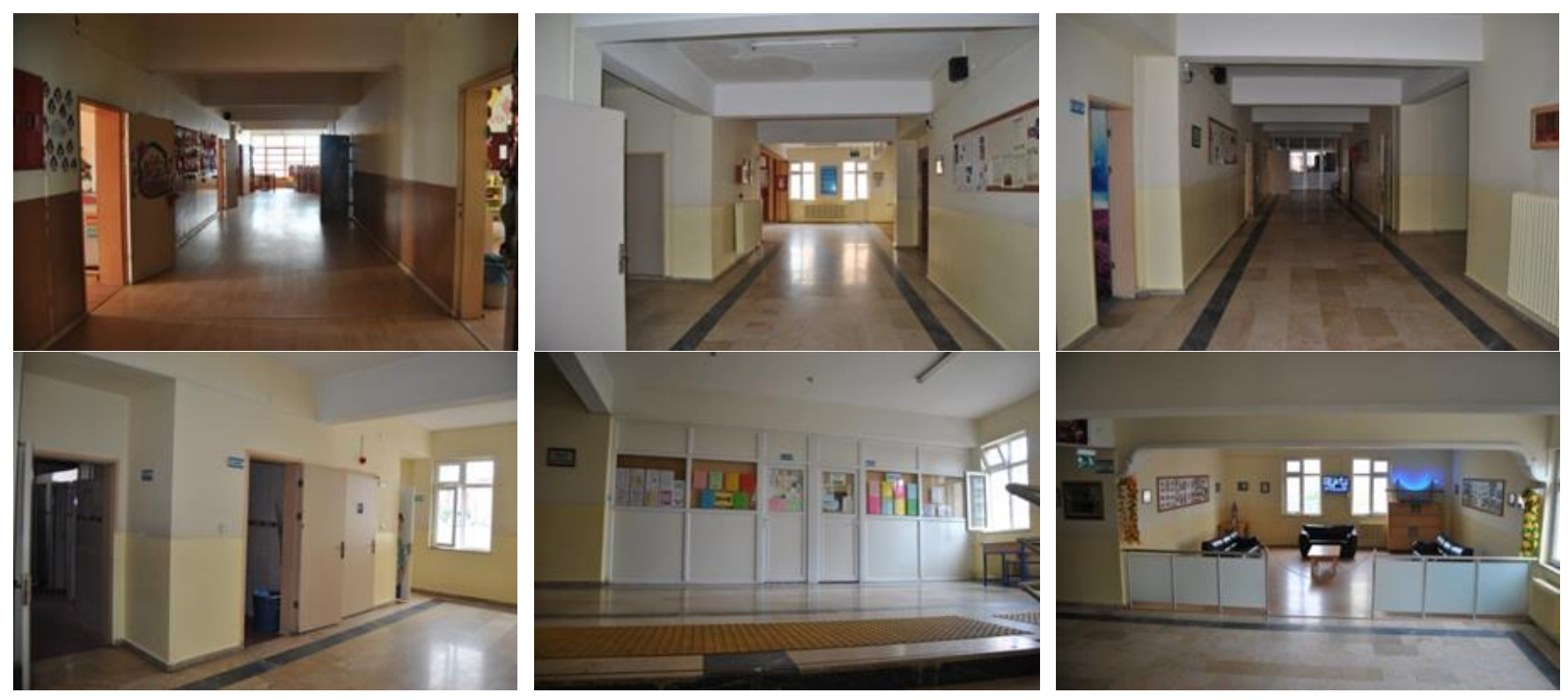

Şekil 6. Kat hollerinin farklı değerlendirilmesi
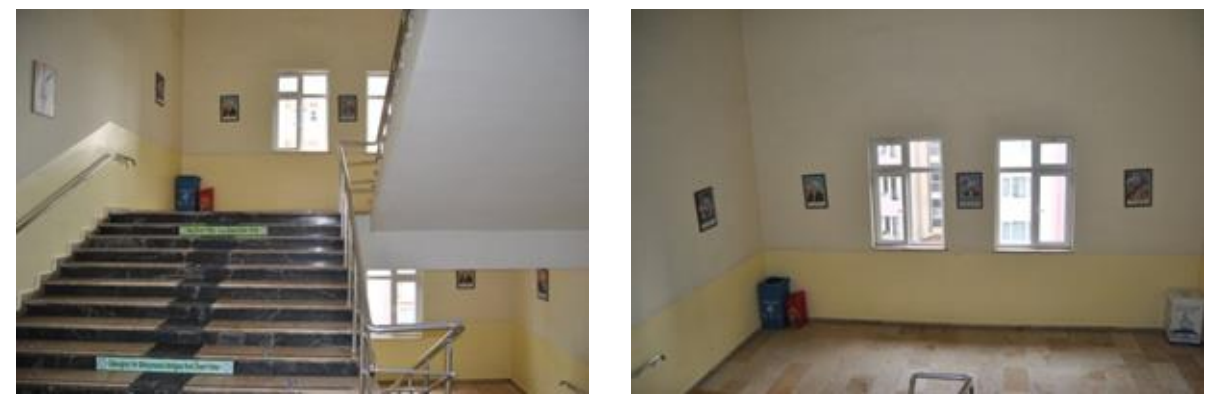

Şekil 7. Ana merdiven

\section{İstanbul Tuzla Tapduk Emre İlkokulu Çevresel So- runları}

İstanbul Tapduk Emre İlkokulu'na dair mevcut yapısal özelliklerin değerlendirilmesi sonucunda aşağıdaki sorunlarla karşılaşılmıştır. Çevresel açıdan iyileştirmeler için öncelikle bu sorunlar dikkate alınacaktır. Seçilen okul kapsamında varılan bu sonuçların Türkiye genelindeki tip ilkokul yapılarında da olduğu düşünülmektedir.

- Dış mekân/bahçeye dair malzeme ve yeşil miktarı önemsenmemektedir. Zemin döşemesi olarak kullanılan asfalt hem suyun doğal yollarla geri kazanımını engellemekte hem yeşil dokuya imkân vermeyen niteliksiz alanlar oluşturmaktadır.

- Okul bahçesinin otopark olarak kullanılan doğu kısmı; bu alanın öğrenciler tarafından kullanımını engellemektedir. Ayrıca öğrencilerin ve araçların aynı kapıyı kullanarak bahçeye giriş çıkış yapmaları tehlikeye neden olmaktadır. Ders başlangıç ve bitiş saatlerinde yaşanan yoğunluk da aynı nedenden kaynaklanmaktadır.
- Yenilenebilir enerji kaynakları kullanımı ile ilgili bir çaıışma bulunmamaktadır. Çünkü bu başlık çoğunlukla maliyetli bulunmakta ve mevcut ekonomik koşullar bu duruma cevap verici nitelikli değildir.

- Okul bahçesinde çok az miktarda kullanılan yeşil doku ve peyzaj ögeleri; bahçeyi tanımsız hale getirmektedir. Küçük yaş grubu çocuklar için nitelikle bir alan ve oyun mekânı sunulmamaktadır. Güneşten ve yağmurdan korunum için ek tedbirler gerektirmektedir.

- Çatıdan yağmur olukları ile toplanan yağmur suları doğrudan kanalizasyona verilmektedir. Böylece yoğun yağışların yaşandığı bahar ve kış aylarında taşmalara neden olmaktadır.

- Islak hacimlerde su tasarruflu ekipmanların olmaması su tüketim miktarını arttırmaktadır.

- Pencerelerin tek yönlü yanal açılımı özellikle küçük yaş grubu çocuklar için tehlike oluşturmaktadır. Ayrıca bu durum doğal havalandırma yapılmasını engellemektedir. 
- Güneş kontrolü amaçlı cephede herhangi bir eleman kullanılmamaktadır. İç mekânda kullanılan perdeler ise güneş ışığını kontrol altına almak için yeterli nitelikte değildir. Bu yüzden sınıflardaki doğal aydınlatma ve havalandırma kalitesi düşmektedir.

- Akustik kontrol amaçılı iç mekanlarda hiçbir ekipman ve malzeme bulunmamaktadır. Bu durum özellikle toplu kullanım alanlarında yoğun gürültüye neden olmaktadır.

- Tapduk Emre İlkokulu mevcut konut dokusu içerisinde yer aldığı için öğrencilerin yaklaşık \%80'i okula yürüyerek gelmektedir. Öğrencilerin bir kısmı servis bir kısmı ise otobüsle; öğretmenler ise özel araçlarıyla ya da otobüslerle ulaşımlarını sağlamaktadır.
- Genel olarak düşük gelir seviyesine sahip olan bu bölgenin sürdürülebilir çalışmalar hakkında bilgi sahibi olmadıkları düşünülmektedir. Ancak; okuldaki çalışmalara ve etkinliklere katılan bölge halkının sürdürülebilirlik kapsamında yapılacak çalışmalara da katılacakları düşünülmektedir.

\section{Tapduk Emre İlkokulu Ekolojik İyileştirme Önerileri}

Yukarıda açıklanan sorunları azaltacak iyileştirme önerileri başlıklar halinde ve şematik olarak aşağıda sunulmaktadır (Şekil 9). Yurt dışında bununla ilgili örneklere de rastlamak mümkündür.

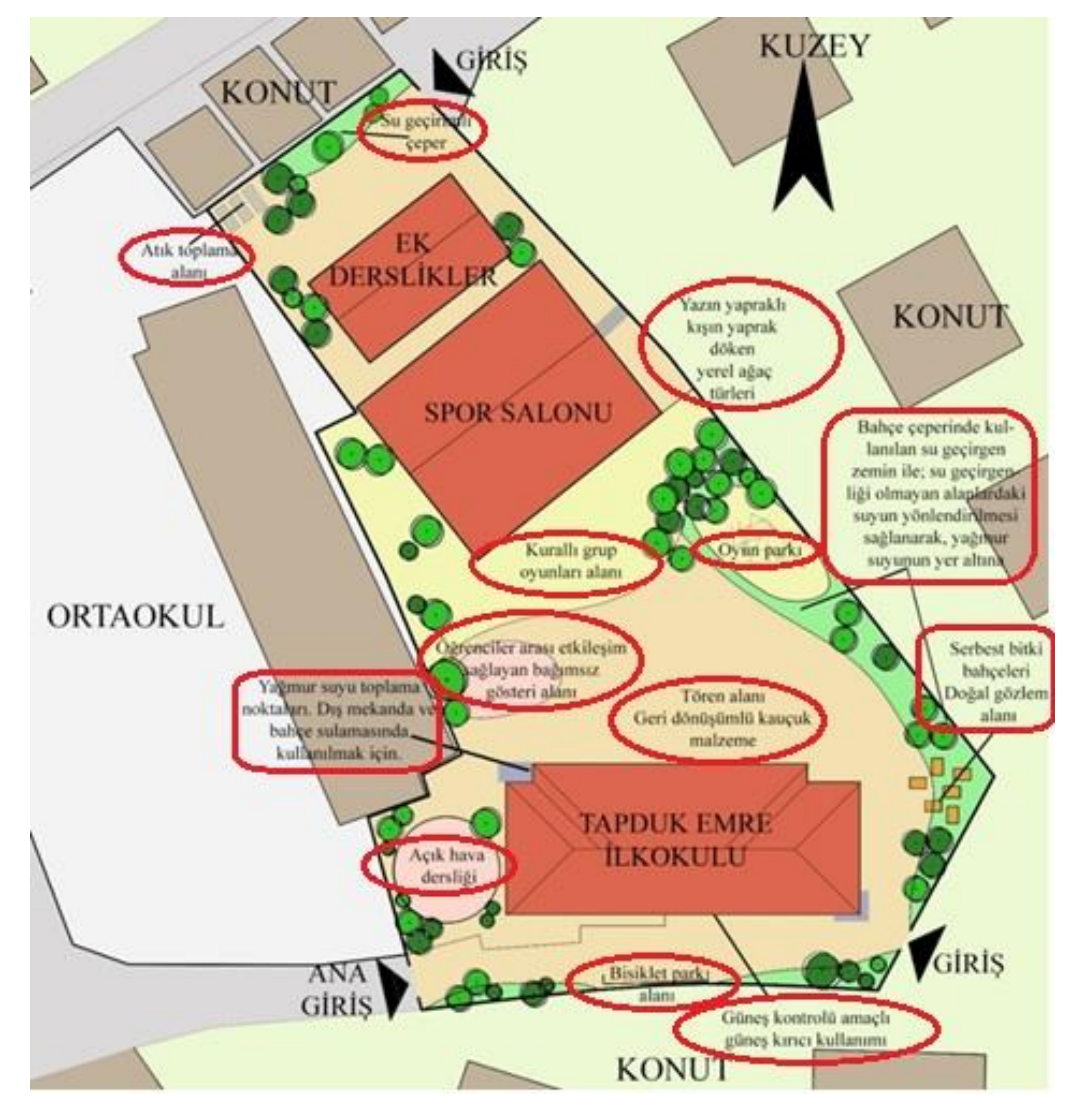

Şekil 8. İstanbul Tapduk Emre İlkokulu bahçesi kullanımı önerisi şematik gösterimi

\section{Peyzaj düzenlemesi}

- Bahçenin kuzey yönünde yapılacak ağaçlandırma çalışması ile, bu yönden gelecek rüzgar etkisini azaltılabilir.
- Bahçeye yerleştirilecek küçük bitki bahçeleri ile öğrencilerin farklı bitki türlerini yetiştirmeleri ve bu konuda bilgi sahibi olmaları sağlanabilir (Şekil9). Böylece okul bahçesi daha fazla yeşil alana sahip olan, nitelikli bir hale kavuşur. Aynı zamanda öğrencilerin gözlem gücünü arttıracak bu etkinlik ile sorumluluk bilinci de verilebilir. 


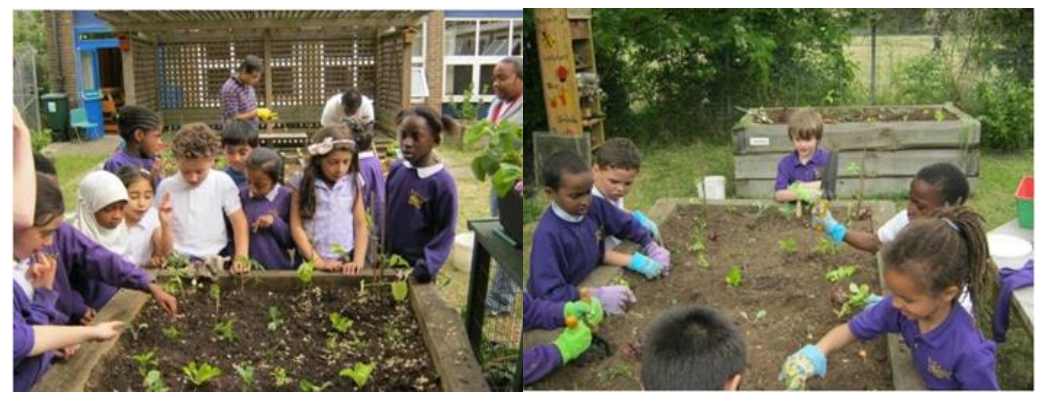

Şekil 9. Kingsmead İlkokulu bitki bahçeleri (Gökmen, 2012)

- Mevcut dokuya verilmiş olan zararın iyileştirme çalışmaları yapılabilir. Böylece bundan sonra verilebilecek olan zararları en aza indirmek sağlanabilir.

- Mevcutta bulunan atık toplama alanının güney cephede bulunan kazan dairesi hizasında alt kota taşınabilir. Böylece kullanım açısında daha güvenli ve sağlıklı olabilir. Ayrıca bu atıkların çevreye en az zarar verecek şekilde yok edilmesi ya da geri dönüştürülmesi ile ilgili çalışmaların araştırılması ve yapılması bir etkinlik konusu olabilir.

- Okul bahçesine araç girişi almayarak mevcutta otopark olarak ayrılan kısmı bahçe kullanımına dâhil edilebilir. Okul duvarını da sınırlayan yandaki site ile anlaşarak araç parkını o bölgede otopark olarak ayrılan bir alanda sağlanabilir. Böylece bahçe içi güvenlik arttırılmış olur.

\section{Enerji korunumuna yönelik iyileştirmeler}

- Yapı cephesinde özellikle yoğun güneş alan cephelerde, güneşin cephedeki yapı elemanlarını ısıtmasını engellemek aynı zamanda mikroklimatik iyileştirme sağlayacak dikey bahçe düzenlemesi yapılabilir. Uygun cephelere çelik iskeletli kafes sistem yerleştirilerek sarmaşık vb. bitkilerin yetişmesi sağlanabilir.

- Sınıfların daha fazla doğal ışıkla aydınlatımasını sağlamak amacıyla pencerelere ışık rafları yapılabilir. Işık rafları ışığı daha derin mesafelere taşırken, pencere yakınlarının da direk güneş ışığı almasını engelleyerek kamaşmayı önlemiş olur.
- Sınıfların doğu-batı yönü boyunca olduğu sınıflarda parlama ve ışık kontrolü amaçlı güneş kırıcıların kullanılması gerekmektedir. Böylece iç mekânda sağlıkı bir ortam elde edilmiş olur.

- Dış cephelerde Isı yalıtımı bulunmayan yapılarda, ISı yalıtımı yapılarak yapılarda ısıl konfor sağlanabilir.

- Güneş enerjisinin kullanımı sağlanabilir. Güney cepheye ve çatıya yerleştirilecek güneş panelleri ile enerji kazanımı sağlanabilir. Özellikle sıcak su kullanımı olan ilkokullarda suyun ısıtılması da sağlanarak enerji verimi arttırılabilir.

- Enerji etkin aydınlatma elemanları (Led ampuller gibi) ve ekipman (merkezi iklimlendirme) kullanılarak aktif enerji tüketimi azaltılabilinir.

\section{Su korunumuna yönelik iyileştirmeler}

- Çatılara yapılacak küçük ilavelerle yağmur suları toplanabilir. Okul bahçesinde öğrencilerin tarımsal faaliyetlerini yapacağı bahçenin yakınına yapılacak su deposunda toplanacak yağmur suları bahçenin sulama ihtiyacını karşılayabilir.

- Okul bahçesinde kullanılacak bitkilerde; doğal olarak yetişen, fazla su intiyacı duymayan türler seçilebilir.

- Dış mekân oyun alanlarında kum, çimen gibi su tutucu nitelikte olmayan malzemeler seçilebilir. Aynı zamanda; asfalt ya da sert zemin olarak kullanılacak alanlarda (otopark) yağmur sularının kanalizasyona değil su geçirimli alana yönlendirecek çalışmaların yapılabilir (Şekil 10, 11) 


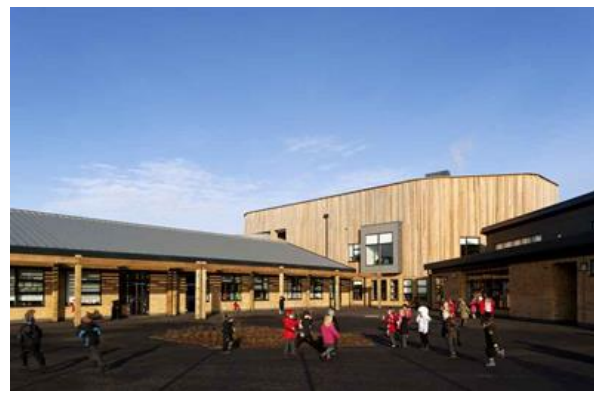

Şekil 10. Carnegie İlkokulu farklı zemin kaplama malzemeleri kullanımı

(URL-1, 2015)

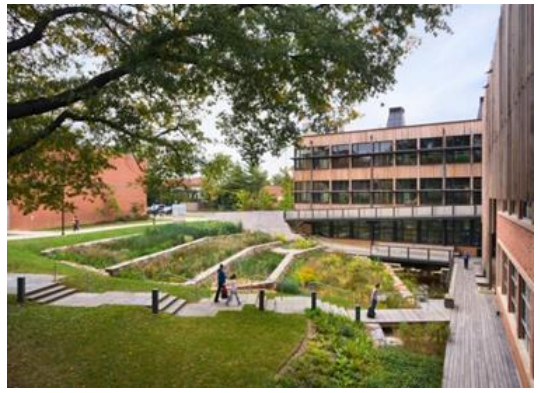

Şekil 11. Sidwell Friends İlkokulu dış mekân zemin çeşitliliği (URL-2, 2015)

mekânlar içi akustik destekli malzemelerin kullanılabilir.

\section{Yerel Dokunun Sosyal, Kültürel ve Ekonomik Du- rumu}

- Yapının eğitim öğretim süreleri dışında; farklı etkinlikler çerçevesinde çevre halk ile kullanımının sağlanabilir. Böylece okul o bölge için bir sembol haline gelebilir.

- Okulun toplumsal gereksinim ve isteklere cevap verici nitelikte olması sağlanabilir.

- Müfredat konularına dahil edilecek ekoloji bilinci ile öğrencilerin hayatları boyunca sürecek alışkanlıkları şekillendirilebilir. Ayrıca okullarının sahip olduğu ekolojik özellikler ile gurur duymaları sağlanabilir.

- Okulun sahip olduğu çevresel özellikler öncelikle öğrenciler daha sonra onların aileleri için öğretici nitelikte olmaktadır. Böylece yakın çevre halkının da bilinçlenmesi sağlanabilir. Ailelerin de katılacağı ortak etkinlikler ile bu etkileşim daha da arttırılabilir.

\section{SONUÇLAR}

Genel olarak bakıldığında; belirlenen sorunların ekonomik kaynaklı olduğu düşünülmektedir. Okullara ayrılan bütçenin yetersizliği ve sürdürülebilirlik kavramının henüz çok fazla önem kazanmamış olması bu konuda çaışmaların gerçekleştirilmemesine neden olmaktadır.

İlkokullarda yapılacak bu iyileştirme çalışmaları ile 7-10 yaş arası çocukların hayatları boyunca sahip olacakları ekoloji bilincini edinmeleri sağlanabilir. Böylece bilinçlenen bir nesil için adımlar atılmaya başlar. Artan enerji ve kaynak tüketimi, yok edilen yeşil doku, artan kirlilik ve çevre sorunları sonucu çevreye verilen zarara dair çözüm olanakları geliştirilmiş olur.

Türkiye'deki ilkokulların tip projeler olarak uygulandığı bilinmektedir. Tapduk Emre İlkokulu özelinde bulunulan öneriler; diğer ilkokul yapılarında da uygulanabilir nitelik- 
tedir. Böylece mevcut tip ilkokul yapılarının yaşam ömrünün bitmesi beklenmeden sürdürülebilir nitelikler kazanmaları sağlanabilir.

Mevcut yapı stokunun çok fazla olması sürdürülebilir çaIışmaların yapılmasına engel değildir. Özellikle bu bilincin verildiği çağlar olan 7-10 yaş arası çocukların eğitim gördüğü ilkokul yapıları bu konuda ayrı bir öneme sahiptir. Var olan ilkokul yapılarının en az değişiklik ve en akılcı çözümlerle sürdürülebilir nitelikler kazanmaları mümkündür. Böylece sürdürülebilir niteliklere sahip okullar elde ederek bu okullarda eğitim alan nesillerin bilinçlenmesi sürdürülebilirlik kavramının içselleştirilmesi sağlanabilir. Mimarların ve MEB'in ortak yürütebileceği iyileştirme projesi kapsamıyla nitelikli, yaşayan ve yaşatan ilkokullar elde edilebilir.

\section{KAYNAKLAR}

Dorsey, J., L'Esperance, C., (2000). Sustainable Design Guidelines for the Construction of New Facilities and the Renovation of Existing Structure. Education Resources Information Center (ERIC), USA, http://www.eric.ed.gov/PDFS/ED454689.pdf,

Dudek, M., (2000). Architecture of Schools: The New Learning Environments. Architectural Press, London, UK.

Dudek, M., (2007). Schools and Kindergartens (Design Manuals). Birkhauser. Berlin, Germany.

Earthman, G. I. (2002). School Facility Conditions and Student Academic Achievement. UCLA's Institute for Democracy,
Education and Access, Williams Watch Series, Los Angeles, USA.

Ford, A., (2007). Designing the Sustainable School. Bastow The Images Publishing Group, , Victoria, Australia.

Gelfand, L., (2010). Sustainable School Architecture: Design for Primary and Secondary Schools. John Wiley \& Sons, Canada.

Gökmen, H. S., (2012). Çevre Duyarlı Mimarlık, Sürdürülebilir Okul Örneklerine Bir Bakış. Mimarlık Dergisi, 368: 53-58.

LPA., (2009). Green School Primer: Lessons in Sustainability. Bastow The Images Publishing Group, Victoria, Australia.

Maiden, J. ve Foreman, B. A., (1998). Cost, Design and Climate: Building a Learning Environment. School Business Affairs, 64(1): 40-44.

MEB (2016). Öğrenci sayısı 17 milyon 588 bine yükseldi, http://www.meb.gov.tr/ogrenci-sayisi-17-milyon-588-bineyukseldi/haber/10675/tr

Meek, A. (1995). Designing Places for Learning, Association for Supervision and Curriculum Development. Alexandria, USA.

Taylor, A., (2009). Linking Architecture and Education: Sustainable Design of Learning Environments. University of New Mexico Press, China.

Tonguç, B., (2012). Sürdürülebilir Tasarımın Okul Öncesi Eğitim Yapıları Örneğinde İrdelenmesi, Yüksek Lisans Tezi, Kocaeli Üniversitesi, Fen Bilimleri Enstitüsü, Mimarlık Anabilim Dalı, Kocaeli, Türkiye.

URL-1, (2015). http://www.e-architect.co.uk/scotland/carnegie-primary-school (Erişim tarihi: 16.01.2015)

URL-2, (2015) http://www.archdaily.com/32490/ad-interviewskieran-timberlake/ (Erişim tarihi: 15.01.2015) 